\title{
Micro-Organisms in the Intestines of Earthworms
}

\author{
By J. N. PARLE \\ Soil Microbiology Department, Rothamsted Experimental Station, \\ Harpenden, Hertfordshire*
}

(Received 28 June 1962)

\begin{abstract}
SUMMARY
Actinomycetes and bacteria, but not fungi, increase rapidly in numbers during the passage of food through the worm gut. Enzymes produced by the worm rather than micro-organisms seem to be the main agents digesting cellulose and chitin. The rate that material moves through the intestine depends on whether the animal is feeding; food takes about $20 \mathrm{hr}$. to pass, but when burrows are being formed material passes in about $12 \mathrm{hr}$.
\end{abstract}

\section{INTRODUCTION}

The influence of earthworms on soil formation and in changing the structure of agricultural soil has received considerable attention, but little has been published on the effects of worms on the soil microflora. Bassalik (1913) found no qualitative difference between the microflora of the worm gut and surrounding soil, but Aichberger (1914) found the worm gut to differ from the soil in containing no lice, yeasts, desmids, rhizopods, or blue green algae. Dawson (1947) compared aggregates formed in the worm intestine with those from casts and soil and found fewer bacteria in intestinal aggregates but no differences in the fungi. By using an enrichment technique Khambata \& Bhat $(1953,1955,1957)$ studied specific groups of bacteria in the worm intestines and isolated oxalate and cellulose decomposers, but no nitrifying organisms. Hutchinson \& Kamel (1956) isolated viable thick-walled and thin-walled fungal spores from worm gut and showed that the fungi were dispersed more rapidly in sterilized soil containing worms, than when worms were absent. The present work follows the changes in the microbial population in ingested material as it passes through the worm, and attempts to evaluate benefits the worm may derive therefrom.

\section{METHODS}

Earthworms. Three species were studied: Lumbricus terrestris (Linn.), Allolobophora caliginosa (Sav.) and Allolobophora terrestris (Sav.) form longa (Ude), which will be referred to as $A$. longa to avoid confusion with $L$. terrestris. All specimens were collected from the same soil at Rothamsted, a flinty silt loam $\mathrm{pH} 6.5$ of the Batcombe Series, which had been under permanent pasture for 70 years (Great Field IV).

Media. Soil extract agar (Lochhead \& Burton, 1956) was used to count bacteria, and sodium asparaginate agar (Conn, 1921) for actinomycetes. Filamentous fungi

* Present address : Rukuhia Soil Research Station, P.B. Hamilton, New Zealand.

Vol. 30, No. 3 roas issued 20 March 1963 
were counted on a glucose peptone agar, containing $10 \%$ glucose, $0.5 \%$ peptone, $0.1 \% \mathrm{KH}_{2} \mathrm{PO}_{4}, 0.05 \% \mathrm{MgSO}_{4}, 7 \mathrm{H}_{2} \mathrm{O}$ and $2 \%$ agar, and yeasts on Sabouraud agar (Anderson, 1917) both of which were at $\mathrm{pH} 7 \cdot 0$ and contained $30 \mathrm{mg}$. aureomycin $/ \mathrm{ml}$., added just before inoculation to inhibit growth of bacteria. For chitinolytic organisms a medium devised by Veldcamp (1955) was used and for cellulose decomposers Jensen's (1940) mineral salt solution with filter-paper strips. All media, except Sabouraud agar, were dispensed in $4 \mathrm{ml}$. lots in test tubes. The yeasts when grown in tubes were obscured by other fungi and were therefore surface inoculated on to Petri plates.

Cellulose suspension for metabolic studies was prepared from high-quality cottonwool broken up by soaking overnight in conc. $\mathrm{HCl}$ at $5^{\circ}$. This was then dispersed in a large volume of water and further macerated in a Waring blender. The fine particles were separated by decantation, ground for $\mathbf{2 4} \mathrm{hr}$. in a ball mill, and the slurry formed was diluted with water to give a suspension containing $2 \%(w / v)$ of cellulose.

Chitin suspension was prepared from the shells of Sepia officinalis by the method of Clarke \& Tracey (1956).

Reducing sugar was determined by the modified Somogyi-Nelson method (Nelson, 1944) after precipitation of protein with $\mathrm{ZnSO}_{4} / \mathrm{Ba}(\mathrm{OH})_{2}$ reagents. Acetyl glucosamine was determined by the method of Morgan \& Elson (1934).

Collection of samples and counting procedure. Earthworms were collected by digging, and at the same time soil samples of 40-60 g. were taken. Worms were washed free from soil and batches of five were killed by brief immersion in water at $48^{\circ}$ and dissected immediately. Samples of gut contents of about $0.5 \mathrm{~g}$. dry weight were placed in $\mathbf{5 0 ~ m l}$. sterile distilled water in weighed screw-capped bottles, which were shaken at 200 strokes per min. for $20 \mathrm{~min}$. A series of two-fold dilutions was prepared from this suspension by using silicone-coated pipettes which were changed frequently. Two samples were taken from each dilution into each culture medium. Tube cultures were sloped to give a thin layer of medium to facilitate counting. The number of organisms present was estimated from the total number of cultures showing growth (Fisher \& Yates, 1938).

Soil samples were sieved through $1 \mathrm{~mm}$. mesh and subsamples were taken for a similar dilution series. When dilutions had been prepared, the original samples were dried at $105^{\circ}$, weighed and all counts corrected to numbers per g. dry weight of soil or gut contents.

\section{RESULTS}

The microflora of the gut contents of three species of worm

Table 1 gives counts on composite samples from all sections of the gut of Lumbricus terrestris, Allolobophora caliginosa, and A. longa. For the first two species, which feed actively for most of the year, the samples were collected during June and July. Over this period Allolobophora longa was aestivating, with an almost empty gut containing many fewer organisms than soil. The $A$. longa counts were from feeding worms collected in September and October.

Many more actinomycetes and bacteria were isolated from the gut of each species than from the soil. The differences between the soil and gut counts were highly significant, in spite of the large variation between samples. Allolobophora caliginosa 
contained more yeasts than Lumbricus terrestris probably because it was eating more; these increases over the numbers isolated from the soil were not significant. Sample variances of fungal counts of both soil and gut contents were large. The

Table 1. Counts of yeasts, fungi, actinomycetes and bacteria in worm intestinal contents compared with soil. Mean log. number of organisms per g. dry wot. of gut contents or soil

\begin{tabular}{|c|c|c|c|c|}
\hline & Yeasts & $\begin{array}{l}\text { Fungi } \\
\times 10^{6}\end{array}$ & $\begin{array}{c}\text { Actino- } \\
\text { mycetes } \\
\times 10^{6}\end{array}$ & $\begin{array}{c}\text { Bacteria } \\
\times 10^{6}\end{array}$ \\
\hline \multicolumn{5}{|c|}{ Lumbricus terrestris } \\
\hline Gut content & $\begin{array}{c}4 \cdot 39 \\
\pm 0 \cdot 122\end{array}$ & $\begin{array}{l}-0 \cdot 25 \\
\pm 0 \cdot 122\end{array}$ & $\begin{array}{c}1.97 \\
\pm 0.154\end{array}$ & $\begin{array}{c}4.91 \\
\pm 0.166\end{array}$ \\
\hline Soil & $\begin{array}{c}4.70 \\
\pm 0 \cdot 178\end{array}$ & $\begin{array}{l}-0 \cdot 50 \\
\pm 0 \cdot 164\end{array}$ & $\begin{array}{c}0.95 \\
\pm 0 \cdot 226\end{array}$ & $\begin{array}{c}2.07 \\
\pm 0.244\end{array}$ \\
\hline \multicolumn{5}{|c|}{ Allolobophora caliginosa } \\
\hline Gut content & $\begin{array}{c}5.06 \\
\pm 0.070\end{array}$ & $\begin{array}{l}-0.08 \\
\pm 0.081\end{array}$ & $\begin{array}{c}3 \cdot 12 \\
\pm 0 \cdot 198\end{array}$ & $\begin{array}{c}4.42 \\
\pm 0.342\end{array}$ \\
\hline Soil & $\begin{array}{c}4.79 \\
\pm 0.103\end{array}$ & $\begin{array}{l}-0.39 \\
\pm 0.119\end{array}$ & $\begin{array}{c}1 \cdot 54 \\
\pm 0 \cdot 290\end{array}$ & $\begin{array}{c}2.06 \\
\pm 0.500\end{array}$ \\
\hline \multicolumn{5}{|c|}{ A. longa } \\
\hline Gut content & $\begin{array}{c}5 \cdot 46 \\
\pm 0 \cdot 074\end{array}$ & $\begin{array}{c}0.52 \\
\pm 0.068\end{array}$ & $\begin{array}{c}3 \cdot 25 \\
\pm 0 \cdot 102\end{array}$ & $\begin{aligned} & 5 \cdot 30 \\
\pm & 0.070\end{aligned}$ \\
\hline Soil & $\begin{array}{c}5 \cdot 00 \\
\pm 0 \cdot 109\end{array}$ & $\begin{array}{c}0 \cdot 15 \\
\pm 0.099\end{array}$ & $\begin{array}{c}1 \cdot 00 \\
\pm 0 \cdot 149\end{array}$ & $\begin{array}{c}2 \cdot 03 \\
\pm 0 \cdot 103\end{array}$ \\
\hline
\end{tabular}

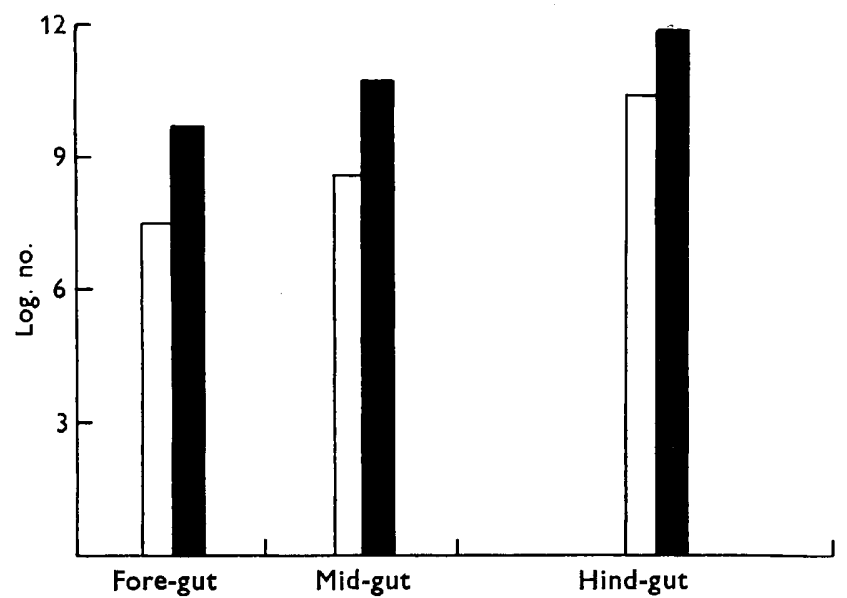

Fig. 1. Number of bacteria and actinomycetes in the various sections of the gut of $\boldsymbol{L}$. terrestris. $\mathbf{E}$, bacteria; $\square$, actinomycetes.

differences between the number of fungi recovered from different samples probably depended on differences in the fungal content of the food. When counts were very high, one species, usually a Penicillium, was dominant.

Both actinomycetes and bacteria increased greatly in the gut of Allolobophora long $a$ as with the other species, but this worm also contained more fungi and yeasts 
than soil (significant at the $5 \%$ level). The reasons for these small increases are not clear; they may have come from differences between the soil sampled and the actual material eaten by the worm.

Actinomycetes and bacteria in different sections of the gut were counted in samples of 25 Lumbricus terrestris, collected in groups of five. After dissection, the intestine was divided into the following sections, each of which was measured; foregut (buccal cavity, oesophagus, crop and gizzard), mid-gut and hind-gut, and a separate sample was taken from each. The results in Fig. 1 are plotted along an abscissa representing the length of the worm's intestine with the counts entered in positions corresponding to the middle of each section of gut. The bacteria and actinomycetes increased in number throughout their passage through the worm, the increases tending to be logarithmic.

\section{Cellulolytic activity in the intestine of earthworms}

Worms feed largely on dead plant and insect material and the large increase in the bacterial and actinomycete populations during passage of food through the gut suggests that cellulolytic (and chitinolytic) organisms might be selectively increased. Tracey (1951) found evidence for the presence of cellulase and chitinase in aqueous extracts of several earthworm species but did not determine the source of these enzymes.

Counts of cellulose decomposers in the intestinal contents were irregular and an indirect method based on oxygen uptake (Schmidt \& Ruschmeyer, 1958) was used. Samples of gut contents of Lumbricus terrestris of approximately $1 \mathrm{~g}$. dry weight of material were suspended in $10 \mathrm{ml}$. phosphate buffer $(\mathrm{pH} \mathrm{7 \cdot 0)}$. Warburg flasks were prepared containing $3 \mathrm{ml}$. of this suspension and with $0.5 \mathrm{ml} .2 \%$ cellulose suspension as substrate; in control flasks $0.5 \mathrm{ml}$. water replaced the cellulose substrate. Flasks were shaken and oxygen uptake was measured at $25^{\circ}$. Readings were made hourly for $12 \mathrm{hr}$. on 3 consecutive days (Chase \& Gray, 1957); the results are shown in Table 2.

Table 2. Oxygen uptake of gut contents from Lumbricus terrestris

$\begin{array}{ccc}\text { Day } & \overbrace{\text { Control }} & \text { + Cellulose } \\ 1 & 12 \cdot 8 & \mathbf{1 2 . 9} \\ 2 & \mathbf{1 6 \cdot 2} & \mathbf{1 7 . 8} \\ 3 & \mathbf{2 2 \cdot 0} & \mathbf{2 9 \cdot 8}\end{array}$

Initially the $\mathrm{O}_{2}$ uptake was the same for all flasks, but after a short period the respiration rate in those with cellulose increased greatly. This might reflect either the presence of cellulolytic organisms, or the production of glucose by a cellulase from the worm and its metabolism by micro-organisms. Fewer than 1000 cellulolytic organisms per g. dry weight were recovered from flask contents at the end of the 3-day period, so experiments were made to test for a cellulase. 


\section{Cellulolytic activity of total gut contents}

Gut contents were suspended in buffer as described and duplicate sets of flasks prepared with and without added cellulose. To each was added $0.5 \mathrm{ml}$. toluene to stop bacterial activity. Flasks were incubated at $25^{\circ}$ and samples taken at $24 \mathrm{hr}$. intervals were tested for glucose (Table 3). The experiment was repeated with gut contents from mid- and hind-gut sections (Table 4).

Table 3. Glucose production of total gut contents of Lumbricus terrestris $\mu$ g. glucose $/ \mathrm{ml}$.

$\begin{array}{ccc}\text { Day } & \overbrace{\text { Control }} \text { +Cellulose } \\ 0 & 209 & 209 \\ 1 & 232 & 246 \\ 2 & 236 & 256 \\ 3 & 244 & 264\end{array}$

Table 4. Glucose production from mid-and hind-gut contents of Lumbricus terrestris

\begin{tabular}{lcc} 
Day & $\overbrace{\text { Control }}^{\mu \text { + Cellulose }}$ \\
\multicolumn{3}{c}{ Mid-gut contents } \\
o & 216 & 216 \\
1 & 198 & 252 \\
2 & 243 & 378 \\
3 & 342 & 729
\end{tabular}

Hind-gut contents

$\begin{array}{lll}0 & 160 & 160 \\ 1 & 144 & 160 \\ 2 & 216 & 208 \\ 3 & 224 & 208\end{array}$

The results show that an appreciable amount of glucose was present in the freshly prepared suspensions. This increased during incubation, particularly with added cellulose, indicating the presence of cellulolytic enzymes in the absence of bacterial activity. Table 4 shows a higher cellulase activity in the mid-gut section.

Further work on the source of the cellulase was done using gut wall, washed free from the contents. Finely ground portions of the gut wall were suspended in buffer with cellulose and toluene and incubated at $25^{\circ}$. Table 5 shows the results per $\mathrm{ml}$. of suspension containing $0.5 \mathrm{~g}$. wet weight of gut wall.

These results confirm those in Table 4 in showing that cellulose decomposition is restricted to the mid-gut and provide strong evidence that the enzyme is secreted by the worm rather than by organisms occurring in the intestine. The appreciable amounts of glucose in the control series came from the gut wall, and was highest where cellulose decomposition was most active.

Glucose production in toluene-treated suspensions of washed intestinal contents was correlated with oxygen uptake in the Warburg apparatus. Table 6 shows that 
the uptake of oxygen was small and unaffected by the addition of cellulose, indicating that washing removed the enzyme.

Microscopic examination of the intestinal contents stained with chlor-zinc-iodine and of unstained material with polarized light gave no evidence of breakdown of cellulose by bacteria.

Table 5. Glucose production from cellulose by gut wall suspensions of Lumbricus terrestris

$$
\begin{aligned}
& \text { Day } \overbrace{\text { Control +Cellulose }}^{\mu \mathrm{g} \text {. glucose } / \mathrm{ml} \text {. }} \\
& \text { Fore-gut wall } \\
& 160 \quad 160 \\
& 360 \quad 400 \\
& 480 \text { - } 480 \\
& 490 \quad 480
\end{aligned}
$$

\begin{tabular}{|c|c|c|}
\hline \multirow[b]{2}{*}{ Day } & \multicolumn{2}{|c|}{$\mu \mathrm{g}$. glucose $/ \mathrm{ml}$. } \\
\hline & Control & + Cellulose \\
\hline 0 & 30 & 30 \\
\hline 1 & 36 & 37 \\
\hline 2 & 45 & 44 \\
\hline \multirow[t]{2}{*}{3} & 54 & 52 \\
\hline & \multicolumn{2}{|c|}{$\begin{array}{c}\text { Average oxygen } \\
\text { uptake } \mu \mathrm{l} . / \mathrm{hr} \text {. }\end{array}$} \\
\hline 0 & 10.8 & $12 \cdot 1$ \\
\hline $\mathbf{1}$ & $11 \cdot 1$ & $11 \cdot 4$ \\
\hline 2 & 16.2 & $16 \cdot 0$ \\
\hline 3 & 14.0 & $14 \cdot 4$ \\
\hline
\end{tabular}

Hind-gut wall

$\begin{array}{llll}\mathbf{0} & \mathbf{2 4 0} & \mathbf{2 4 0} \\ 1 & \mathbf{4 4 4} & \mathbf{3 8 4} \\ \mathbf{2} & \mathbf{6 1 2} & \mathbf{5 7 6} \\ \mathbf{3} & \mathbf{7 9 2} & \mathbf{6 1 4}\end{array}$

Table 6. Glucose production and oxygen uptake by washed gut contents of Lumbricus terrestris

Chitinase activity in earthrorms

Microscopic examination of the intestinal contents showed numerous fragments of chitinous material, mainly insect cuticle. Many bacteria attack chitin (Veldkamp, 1955; Clarke \& Tracey, 1956): this complicates the problem of deciding whether it is the earthworm or the micro-organisms which produce the chitinase found by Tracey (1951). Chitinase activity and the number of chitin decomposers were measured in different parts of the gut content and gut wall. In principle these 
experiments were similar to those on cellulose breakdown. Acetylglucosamine production was measured after incubation of gut contents with chitin. Tables 7 and 8 show chitinase activity in gut content and gut wall. Acetylglucosamine production by gut content was small, near the limit detectable by the method, but was always larger with chitin. The high values obtained from the fore-gut wall (Table 8) indicated the presence of chitinous material other than that added in the experiment. This was probably the horny material from the gizzard, and in a second experiment this was removed by dissection as far as possible. This was only partly successful; similar results were obtained, the mid- and hind-gut having higher glucosamine contents in the presence of chitin (Table 9).

Table 7. Chitinase in gut content of Lumbricus terrestris

\begin{tabular}{ccc} 
Day & \multicolumn{2}{c}{$\begin{array}{c}\mu \text { g. acetyl } \\
\text { glucosamine/ml. }\end{array}$} \\
\multicolumn{4}{c}{ Control } & Chitin \\
& \multicolumn{2}{c}{ Mid-gut } \\
0 & 1.5 & 1.5 \\
1 & $\mathbf{2 . 0}$ & 3.5 \\
2 & 1.5 & 3.5 \\
& \multicolumn{3}{c}{ Hind-gut } \\
0 & 0.6 & 0.8 \\
1 & 0.8 & 4.5 \\
2 & 1.4 & 5.8
\end{tabular}

Table 8. Chitinase in gut wall of Lumbricus terrestris

\begin{tabular}{|c|c|c|}
\hline \multirow[b]{2}{*}{ Day } & \multicolumn{2}{|c|}{$\begin{array}{c}\mu \mathrm{g} . \text { acetyl } \\
\text { glucosamine } / \mathrm{ml} \text {. }\end{array}$} \\
\hline & Control & Chitin \\
\hline & \multicolumn{2}{|c|}{ Fore-gut } \\
\hline 0 & $3 \cdot 5$ & $\mathbf{3 \cdot 5}$ \\
\hline 1 & $12 \cdot 0$ & $11 \cdot 0$ \\
\hline \multirow[t]{2}{*}{2} & $20 \cdot 0$ & $15 \cdot 5$ \\
\hline & \multicolumn{2}{|c|}{ Mid-gut } \\
\hline 0 & $2 \cdot 2$ & $2 \cdot 2$ \\
\hline 1 & $2 \cdot 1$ & $\mathbf{3 \cdot 3}$ \\
\hline \multirow[t]{2}{*}{2} & $3 \cdot 0$ & $5 \cdot 1$ \\
\hline & \multicolumn{2}{|c|}{ Hind-gut } \\
\hline 0 & $1 \cdot 8$ & $1 \cdot 8$ \\
\hline 1 & $2 \cdot 1$ & 4.5 \\
\hline 2 & $3 \cdot 0$ & $3 \cdot 6 *$ \\
\hline
\end{tabular}

* This sample became contaminated and acetylglucosamine was destroyed by bacteria.

Table 10 shows that, on average, chitin-decomposing micro-organisms were ten times more abundant in the hind-gut than in the mid-gut. These results suggest that chitin breakdown is promoted by bacterial activity as well as by enzymes produced by the worm. 
Rate of food movement through the worm intestine

In the results reported so far, attention was paid only to factors affecting the food material as it passed through the earthworm intestine. Few conclusions can be drawn about the effect of worms on either the microbial population or the ingested material, unless the time required for food to pass through the worm is known.

Table 9. Chitinase in gut wall of Lumbricus terrestris

\begin{tabular}{|c|c|c|}
\hline \multirow[b]{2}{*}{ Day } & \multicolumn{2}{|c|}{$\begin{array}{c}\mu \mathrm{g} . \text { acetyl- } \\
\text { glucosamine/ml. }\end{array}$} \\
\hline & Control & Chitin \\
\hline & \multicolumn{2}{|c|}{ Fore-gut } \\
\hline 0 & $12 \cdot 5$ & $12 \cdot 5$ \\
\hline 1 & $37 \cdot 5$ & $\mathbf{3 7 . 5}$ \\
\hline 2 & $50 \cdot 0$ & $50 \cdot 0$ \\
\hline \multirow[t]{2}{*}{$\mathbf{3}$} & $56 \cdot 2$ & $56 \cdot 2$ \\
\hline & \multicolumn{2}{|c|}{ Mid-gut } \\
\hline 0 & $13 \cdot 3$ & $13 \cdot 3$ \\
\hline 1 & $16 \cdot 6$ & $23 \cdot 3$ \\
\hline 2 & $20 \cdot 0$ & $\mathbf{3 3 \cdot 3}$ \\
\hline 3 & $23 \cdot 3$ & $36 \cdot 7$ \\
\hline & \multicolumn{2}{|c|}{ Hind-gut } \\
\hline 0 & $11 \cdot 1$ & $11 \cdot 1$ \\
\hline 1 & $13 \cdot 9$ & $25 \cdot 0$ \\
\hline 2 & $13 \cdot 9$ & $\mathbf{3 3 \cdot 3}$ \\
\hline 3 & 16.7 & $41 \cdot 7$ \\
\hline
\end{tabular}

Table 10. Chitin decomposers/g. dry wt. in gut contents of Lumbricus terrestris

\begin{tabular}{ccc} 
& \multicolumn{2}{c}{$\begin{array}{c}\text { Number in } \\
\text { millions/g. dry wt. }\end{array}$} \\
Sample & $\overbrace{\text { Mid-gut }}^{\text {Hind-gut }}$ \\
1 & $\mathbf{1 7 \cdot 9}$ & $\mathbf{2 2 8 \cdot 8}$ \\
$\mathbf{2}$ & $\mathbf{3 7 \cdot 3}$ & $\mathbf{1 1 4 \cdot 4}$ \\
$\mathbf{3}$ & $\mathbf{3 8 \cdot 2}$ & $\mathbf{7 8 6 \cdot 2}$ \\
4 & $\mathbf{2 8 \cdot 6}$ & $\mathbf{1 1 2 \cdot 4}$ \\
5 & $\mathbf{5 3 \cdot 1}$ & $\mathbf{6 3 2 \cdot 3}$ \\
Mean & $\mathbf{3 5 \cdot 0}$ & $\mathbf{3 7 4} \cdot 8$
\end{tabular}

Something is known about food movement in insects. Snipes \& Tauber (1937) studied Periplaneta americana, Wedberg \& Clarke (1947) Blaberus cranifer, and Sinha (1958) the stored-grain beetle, but these insects were starved for a period before the experimental feeding. This was considered undesirable for the present investigation because nothing appears to be known about the effects of starvation on food movement.

Several compounds were tried as markers of either food or soil. Sudan IV was not readily recovered and Malachite green poisoned worms. Diatomaceous earth was also tried, but the $5 \%$ which it was necessary to add so irritated Allolobophora 
caliginosa that the material was passed through the gut in $2 \mathrm{hr}$. These markers had the further disadvantage that the worms had to be killed to see how far the material had travelled. In an attempt to avoid these difficulties ${ }^{32} \mathbf{P}$ was used to mark soil.

Two lots of $100 \mathrm{~g}$. dry soil were weighed into bottles and ${ }^{32} \mathrm{P}$ as $\mathrm{H}_{3} \mathrm{PO}_{4}$ added in $25 \mathrm{ml}$. water to give $10 \mu \mathrm{c} . / 100 \mathrm{~g}$. and $50 \mu \mathrm{c} . / 100 \mathrm{~g}$. Soils were allowed to equilibrate overnight and the next day five large Lumbricus terrestris were placed in each. Three hours later the worms were removed, adhering soil washed off and a Geiger counter used to measure the distance travelled by the marked soil. Dissection showed that with worms receiving $50 \mu \mathrm{c} / 100 \mathrm{~g}$. an end-point could be measured accurately on live worms. This method was applied to worms removed at intervals from soil, with the results shown in Fig. 2. The distance moved relative to worm-

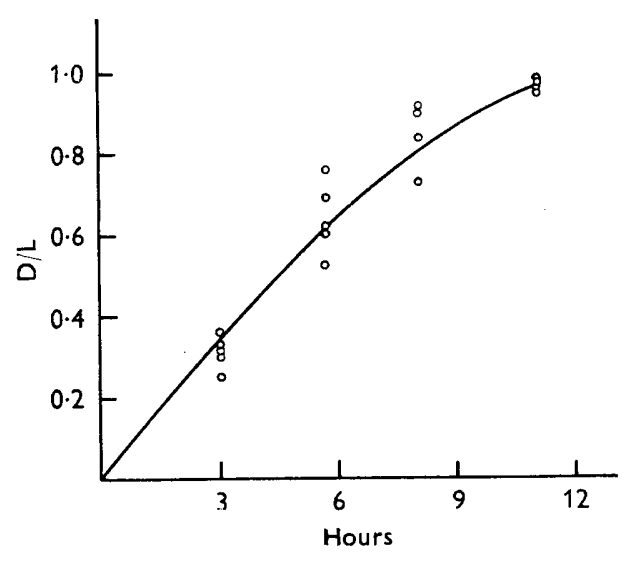

Fig. 2

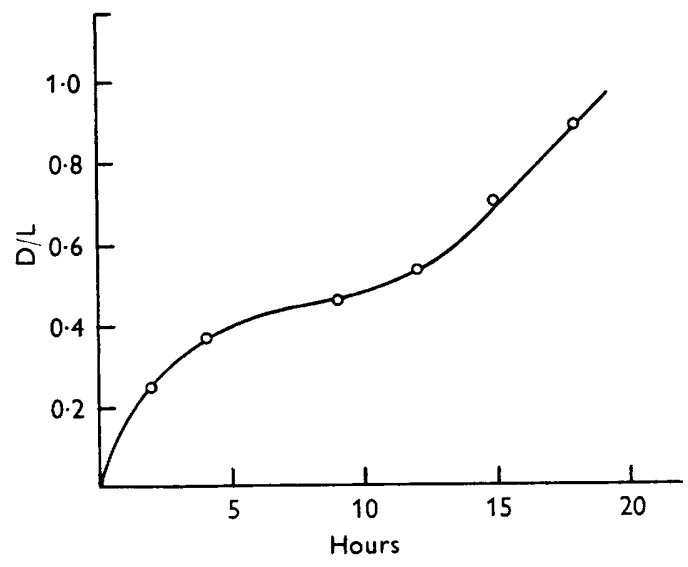

Fig. 3

Fig. 2. Movement of soil through gut of $L$. terrestris.

Fig. 3. Movement of food through gut of $L$. terrestris.

Jength is plotted against time to allow for variation in the size of worms. This experiment gave a value of 11-12 hr. for the full passage of soil and food through the gut of $L$. terrestris, which is too short a time for the soil bacteria to multiply to the extent found in earlier experiments. An explanation for this result was found in the experimental method. Each time the worms were returned to the soil they were forced to make fresh burrows by ingesting soil and so were not, in fact, feeding. To overcome this objection the food instead of the soil was marked. Of several materials tried small pellets made from dung mixed with a dark peat soil were most satisfactory. Mature L. terrestris were kept singly for $48 \mathrm{hr}$. in pots of Barnfield soil, which contains little organic matter, to allow them to make burrows. Three pellets were placed on the surface of the soil in each pot, the pots were then examined at hourly intervals, and the disappearance of pellets recorded. At intervals after the pellets had been taken worms were removed, killed and dissected and the position of the labelled dung + peat recorded. Figure 3 shows the results. Each point represents only one worm; replication was impractical because the worms fed sporadically; on some nights no food was taken. Accuracy was also limited by the fact that observations were made only hourly; nevertheless, it could be concluded that food probably remains in the gut of Lumbricus terrestris for about 
$20 \mathrm{hr}$. A similar value was obtained by Barley (1959) for Allolobophora caliginosa. He also suggested that soil travels more rapidly through the gut of worms when they are burrowing. The flat portion of the above graph where the food travelled more slowly corresponds to the mid-gut, the region of greatest enzyme activity.

\section{DISCUSSION}

A major difficulty in comparing soil itself and soil in the gut of a soil-eating animal is in obtaining comparable samples. Earthworms when feeding not only ingest soil and plant material in different proportions at different times, but they also take in soil non-selectively when making fresh burrows. Pot experiments offer a measure of control impossible in the field, but may introduce other sources of error. An attempt was made to overcome this uncertainty by using a large composite sample from the top few centimetres of soil which includes much of the organic matter in the surface layer upon which worms normally feed. Although this is not an ideal solution, because an empirical choice is involved, the counts obtained for yeasts and filamentous fungi, which did not reproduce in the gut, were substantially the same for soil and gut contents, indicating that the worms ingested material similar to that taken as soil samples. The associated problems of sampling variance were overcome by taking large primary samples and subsampling as required.

Population estimates by the dilution tube technique were much greater than any reported using the plate count. At the highest dilutions showing growth in this method only one or two organisms occurred per culture, so that interference between colonies, well known to be one of the causes of anomalous plate counts, was decreased. Another factor was the use of soil extract agar which gives higher counts than more selective media.

Actinomycetes and bacteria in the gut flora increased greatly in number in all three species of worms. Conditions were less suitable for yeasts or filamentous fungi, which usually did not increase in the gut. The results suggest that changes in the microbial population during passage through the worm gut tended to be logarithmic, indicating that increases were by bacterial growth and not by the worm selecting food material with a high bacterial count. These results are contrary to those of Day (1950) who examined worms kept in pots, where they may not have been feeding normally.

There seems little doubt that cellulose is broken down in the earthworm intestine largely by enzyme secreted by the animal and not by micro-organisms present in the gut. The length of time the food remains in the intestine would not allow much microbial breakdown unless there were very many cellulolytic organisms, and counting did not show a large population of these.

The mode of breakdown of chitin is less clear, but the worm seems to produce some chitinase and there are many organisms in the gut which are able to attack it. How much chitin and cellulose are broken down during passage through the earthworm is not known, but cast material contains considerable amounts of thesematerials. The low temperature and short residence of food in the gut would not allow the breakdown of much resistant material. No evidence was obtained to suggest that the worm had a specialized gut flora, quantitatively different! from that of the soil in which it was feeding. Neither could it be shown, with the possible exception of chitin-decomposing bacteria, that the organisms present helped the worm to digest its food. 
The reason for the increase in numbers of bacteria and actinomycetes remains unexplained. In the absence of evidence that they take a major part in cellulose and chitin breakdown, their increase may come partly from sugars etc. released by enzymic degradation of organic material, and partly from the mechanical action of the worm's oesophagus and gizzard in breaking down the organic matter into a finely divided state in which it is more readily susceptible to microbial attack.

\section{REFERENCES}

Aichberger, R. von (1914). Untersuchungen über die Ernährung des Regenwurmes. Kleinrelt, 6, 53.

Anderson, H. W. (1917). Yeast-like fungi of the human intestinal tract. J. infect. Dis. 21, 341.

BARLEy, K. P. (1959). Earthworms and soil fertility. IV. Influence of earthworms on the physical properties of a red brown earth. Aust. J. agric. Res. 10, 371.

BASSALIK, K. (1913). Úber Silikatersetzung durch Bodenbakterien. Z. GärPhysiol. $2,1$.

Chase, F. C. \& Gray, P. H. H. (1957). Application of Warburg respirometers in studying respiratory activity in soil. Canad. J. Microbiol. 3, 335.

Clarke, P. H. \& Tracey, M. V. (1956). The occurrence of chitinase in some bacteria. J. gen. Microbiol. 14, 188.

Cons, H. J. (1921). The use of various culture media in characterizing actinomycetes. N.Y. Agric. Exp. Sta. Tech. Bull. 83, 3.

Dawson, R. C. (1947). Earthworm microbiology and the formation of water stable aggregates. Proc. Soil Sci. Soc. Amer. 12, 512.

DAY, G. M. (1950). The influence of earthworms on soil micro-organisms. Soil Sci. 69, 175.

Fisher, R. A. \& Yates, F. (1938). Statistical Tables for Biological Agricultural and Medical Research. London: Oliver and Boyd.

Hutchinson, S. A. \& Kamel, M. (1956). The effects of earthworms on the dispersal of soil fungi. J. Soil Sci. 7, 213.

Jensen, H. L. (1940). Nitrogen fixation and cellulose decomposition by soil microorganisms. I. Aerobic cellulose decomposers in association with Azotobacter. Proc. Linn. Soc., N.S.W. 65, 543.

Khambata, S. R. \& Bhat, J. V. (1953). Studies on a new oxalate decomposing bacterium, Pseudomonas oxalaticus. J. Bact. 66, 505.

Khambata, S. R. \& Bhat, J. V. (1955). Flagellated coryneform bacteria from the intestine of earthworms. Arch. Mikrobiol. 22, 175.

Khambata, S. R. \& BHat, J. V. (1957). A continuation to the study of the intestinal microflora of Indian earthworms. Arch. Mikrobiol. 28, 69.

LOCHHEAD, A. G. \& Burton, M. O. (1956). Incidence in soil of bacteria requiring vitamin $\mathrm{B}_{12}$ and the terregens factor. Soil Sci. 82, 237.

Morgan, W. T. J. \& Elson, W. E. (1934). A colorimetric method for the determination of glucosamine and chondrosamine. Biochem. J. 27, 1824 .

Nelson, N. (1944). A photometric adaptation of the Somogyi method for the determination of glucose. J. biol. Chem. 153, 375 .

Schmidt, E. L. \& Ruschmeyer, O. R. (1958). Cellulose decomposition in soil burial beds. I. Soil properties in relation to cellulose degradation. Appl. Microbiol. 6, 108.

Sinta, R. N. (1958). Movements of food in the gut of some adult stored grain beetles. Canad. Entomol. 90, 202.

SNIPEs, B. T. \& Tauber, O. E. (1937). Time required for food passage through the alimentary canal of Periplaneta americana (Linn.). Ann. Ent. Soc. Amer. 30, 277.

Tracey, M. V. (1951). Cellulase and chitinase of earthworms. Nature, Lond. 167, 776.

VELDKAMP, H. (1955). A study of the aerobic decomposition of chitin by micro-organisms. Meded. LandbHoogesh. Wageningen, 55, 127.

Wedberg, E. \& Clarke, N. A. (1947). A simple method for controlled experimentation on the passage of micro-organisms through the digestive tracts of insects. J. Bact. 54, 447 . 